\title{
Zygmunt Bauman'da Toplum ve Toplumsal Düzen Kavramsallaştırması
}

\author{
Fatih Kahraman*
}

Karamanoğlu Mehmet Bey Üniversitesi, Edebiyat Fakültesi, Sosyoloji Bölümü, Karaman.

\section{$\ddot{O} z$}

Toplum ve toplumsal düzenin anlaşılabilmesi, gündelik ilişkilerin yeniden üretildiği toplumun işleyişine ilişkin çıkarım yapabilme imkanı să̆lamaktadır. Toplum ve devamında toplumsal düzenin anlaşılmasına yönelik çaba ise düzeni sağlayan öğelerin birbiriyle ilişkisi bakımından değger taşımaktadır. Toplum ve devamında toplumsal düzeni okuma çabası içerisinde olan sosyologlardan biri ise Zygmunt Bauman'dır. Bu çalşmada Zygmunt Bauman'ın toplum ve toplumsal düzen kavramlarını anlamlandırmak ve açıklayabilmek için başvurduğu kavram gruplar olan, modernite-postmodernite, modernlik, müphemlik ve modern-postmodern etik kavramları ele alınmıştır.

Anahtar Kelimeler:Toplum, Toplumsal Düzen, Müphemlik

\section{Society and Social Order Conceptualization at Zygmunt Bauman}

\section{Abstract}

Understanding the society and the social order provide an opportunity to make deductions about the functioning of the society which reproduces daily relationships. The society and the efforts that aim to understand the social order is of value in terms of the relationship between the elements that provide layout. One of the sociologist that make efforts to understand the society and the social order is Zygmunt Bauman. In this study, Zygmunt Bauman's modernity - postmodernity, modernity, ambiguity and modern - postmodern ethical concepts that aims to explain the society and social order are discussed.

Keywords: Society, Social Order, Ambivalence

\section{GİRIŞ}

Zygmunt Bauman'ın toplum ve toplumsal düzen anlayışının anlamlandırılabilmesinde, modernite-postmodernite, modernlik-müphemlik ve modern-postmodern etik tartışmalarının önemli bir yeri vardır. Özellikle modernliğin çıkış noktası olduğu düzen fikri ve modernliğin belirsizliğe olan tahammülsüzlüğü bu süreci deneyimleyen toplumlar için önemli tehlikeleri ve tek tipleştirmeleri beraberinde getirmekle birlikte, öteki'nin yaratılması ve yaratılan bu toplumsal kesimlerin varlığını çoğunluğun seçimine bırakmasını modern zamanların en büyük çelişkisi olarak ortaya koymaktadır. Müphemliğin, toplumsal düzen karşısındaki rahatsızlığı ve kaos'a giden düzen tartışmaları, modernlik ile müphemliğin uzlaşmaz fakat birbirlerine bağlı ve birbirlerinden etkilenen bir yapı içerisinde var olduklarını göstermektedir. Öteki'nin yok sayıldığı ve onun yaşam hakkının düzenin devamlılığı adına elinden alınması, Bauman'ın modernlik üzerinden toplumsal düzen eleştirisinin ana hatlarıdır. Modern etiğin ahlaka karşı ontoloji (insan birlikteliği) öncelemesinin, bireylerin eylemlerini gerçekleştirirken kendilerinin dışında bir otoritenin baskısı altında kalmalarına neden olduğunu ve postmodern-etik yaklaşımından farklı olarak eylemin sorumluluğunu eylemi gerçekleştirenin üzerine almamasının, öteki'nin 
farkındalığının görmezden gelinmesine neden olduğunu vurgulamaktadır. Bu çerçevede toplum ve toplumsal düzenin Bauman'da görünümü aşağıda, toplum, toplumsal düzen ve etik, müphemlik ve modernlik, modernlik ve postmodernlik durumlarının ilişkisi, başlıkları etrafında tartışılmıştır.

\section{TOPLUM -TOPLUMSAL DÜZEN VE ETIKK ÜZERINNE BİR DEĞERLENIRME}

Bauman toplumu tanımlarken ve toplumsal düzenin anlamlandırılmas ${ }^{1}$ üzerine görüşlerini ortaya koyarken, modern etiğin sorgulanması ve yerine ikame ettiği postmodern-etik anlayışından hareket etmektedir. Toplumun bireylerin dahil olduğu aynı zamanda onları saran bir güç olarak tanımlanmakta ve bireyler gittikten sonrada bu gücün kendisini var edeceği ve sürekliliği olacağını şu cümlelerle belirtmektedir:

“...onaylanan, paylaşılan", "yüceltilen"- paylaşma edimiyle ve paylaşılana saygı duymak için açık ya da zımni bir anlaşmayla yüceltilen. "Toplum" dediğimiz şey tam da bunu yapan devasa bir acayip aygıt; "toplum" onaylama ve paylaşılanı yüceltilmiş hale getiren güçtür. Toplum bu güçtür, çünkü, bizatihi doğa gibi, herhangi birimiz ona ulaşmadan çok önce buradayd ve her birimiz gittikten sonra da burada kalacaktır. "Toplumun içinde yaşamak"onaylamak, paylaşmak ve paylaştığımız şeye saygı göstermek-mutlu yaşamanın (sonsuza dek sürmese de) tek reçetesidir. Toplum der Becker, insan hayatının önemli olduğuna dair canlı bir mit, cüretkar bir anlam yaratma girişimidir..." ve Bauman devam eder: "Bütün toplumlar anlam fabrikalarıdır. Aslında daha da fazlasıdırlar: anlamlı hayatın fidelikleridirler. Verdikleri hizmet vazgeçilmezdir. Topluma tabi olmak, Durkheim'ın işaret ettiği gibi, "özgürleştirici bir deneyim", "kör ve düşüncesiz fiziki güçler"den kurtulup özgürleşmenin tek koşuludur..."2

Toplumun tanımlanması ve toplumsal düzenin mümkünlüğü üzerine akıl yürütmeye devam eden Bauman, Collins'in toplumu anlamlandırma ve kavrayabilme ekseninde vurguladığı, "şeylerdeki düzenin algılanması niteliği olarak ortaya çıkan" şeklinde tanımladığı bilinç kavramından (bazı noktalarda eleştirse de) hareket etmektedir. Bilinç kavramı ekseninde şekil verilmeye çalışılan dünya alg1sı ise karşımıza Hobbes öncesi ve sonrası olarak adlandırılabilecek olan bir toplum imajı çıkarmaktadır³. Bauman, Hobbes öncesi öteki dünyanın, bizim düşünme olarak

\footnotetext{
${ }^{1}$ Toplumsal düzen problemine ilişkin detaylı bir çalışma için bkz. Berivan Binay, Toplumsal Düzen Problemi Ekseninde Anthony Giddens'ın Yapılaşma Teorisi, Yayınlanmamış Doktora Tezi, Adnan Menderes Üniversitesi Sosyal Bilimler Enstitüsü, Sosyoloji ABD, Aydın, 2014.

2Zygmunt Bauman, Bireyselleşmiş Toplum, Çev. Yavuz Alagon, Ayrıntı Yayınları, İstanbul, 2001, s.10.

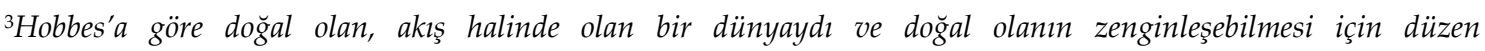
yaratılmalıydı... Artık toplum, önceden tanımlı, dışsal ve varoluşu, hiyerarşik olarak emreden bir şeyin aşkın biçimde ifade bulan bir fikir değildir. Artık toplum, kendisinin atadı̆̆g bir temsilci olan bă̆ımsız devletin emrettiği nominal bir varlıktır..(Elisabeth'in ölümünden kırk yıl sonra) düzen, doğal değil, yapay, insanın yarattığıl, açıkça siyasal ve toplumsal bir şey olarak algılanıyordu... Her taşın altında çıkan (yani, akışkan) şeylerin zaptedilebilmesi için düzen tasarlanmalıydı... Düzen bir iktidar meselesi oldu; iktidar da bir irade, güç ve hesaplama meselesi... Toplum düşüncesinin tamamen yeniden tanımlanması temelinde, tıpkı düzen gibi devletler sisteminin de insanoğlunun yaratısı olduğu inancı vardı... Bkz. Stephen L. Collins, From Divine Cosmos to Sovereign State: An Intellectual
} 
bildiğimiz formda, bugün düzen üzerine düşündügümüz şekilde düzen hakkında hiç düşünmediğini belirtmektedir. Düzenin doğal olmadığının keşfi ise bu bağlamda tam da düzenin kendisinin keşfidir. Bizim düzenin verili-doğal olmadığının farkına varmamı, onun düzensizlik ve daha sert haliyle kaos ile sürdürdüğü diyalektik ilişkiyi anlamlandırmakta ve düzenin tek alternatifinin kaos olduğunu vurgulaması ikili arasındaki etkileşimi ortaya koymaktadır.

"Düzenin ötekisi" olan kaosa salt olumsuzluktur. Bu, düzenin olmak istediği her şeyin reddidir. İşte düzenin olumluluğu, kendisini bu olumsuzluğa karşı kurar. Ancak kaosun olumsuzluğu, düzenin kendini kuruşunun bir sonucudur: Düzenin oluşumunun yan etkisi, artığı, fakat aynı zamanda da düzenin olabilirliğinin sine quanon (olmazsa olmaz) koşuludur. Kaosun olumsuzluğu olmazsa olmaz düzenin olumluluğu da olmaz. Kaos olmadan düzen olmaz."4

Bauman'ın toplum tanımında kaos'un getirdiği belirsizlik üzerinden bireylerin, belirsizliği giderme çabası ve boşluk ile yüzleşememe eğilimi olarak tarif etmektedir. Burada önemli olan nokta Bauman toplumu tanımlarken Cornelius Costariadis'in "örtme operasyonu" teriminden hareket etmekte ve toplum oluşumu ya da göreli bir birlikteliğinin nedenini, bireylerin belirsizlik ve boşluk hissine karşı olan dayanıksızlığı ile açıklamasıdır. Çünkü verili olanın rutinin savurduğu vaatler için en korkutucu şey ona göre Kaos'tur. Toplum, korkudan bir kaçıştır. Aynı zamanda da bu korkunun üreme zeminidir. Costariadis'in cümleleriyle“...insanoğlu, asla tam olarak başarılamadığı için hiç bitmeyen bir Kaos'tan kaçma çabası ile vardır; (ve) toplum, toplumsal kurumlar ve rutinler, toplumsal imgeler ve bunlarm kompozisyonlar, toplumsal yapilar ve bunlarm yönetsel ilkeleri, bütün bunlar işte bu hiç bitmeyen ve dur-durak bilmeyen kaçışın façetalarıdır. Diyebiliriz ki toplum sürekli ve mükemmel bir örtme operasyonudur. Fakat bu kaçışın ortaya çıkarmayı başardı̆̆ı en iyi şey, üzerini örttüğ̈̈̈ Kaos tarafindan sürekli olarak parçalanan, yırtılan ve katlanan ince bir düzen naylonudur..."5

İnsanoğlu, yarattığı düzeni belirleyen, kaos'a karşı koruyan ve kendisinin yönetmediği şeylerin yönetimini devrettiği sürece, kendi kurallarının geçtiği yerde güvende olmaktadır. Ve bu devretme işi ise toplumun gücünün yetmediği ya da risk alamadığı durumlarda bu zaafı Tanrı'nın kadri mutlaklığı, bakiliği ile kapatılabilmektedir. İnsanoğlunun toplumunun, Kaos'a karşı tahammül süresinin az olması ise kendi gerçekliğini ortaya koyabilmesinin mutlaka belirsizliğin giderilebildiği ölçüde giderilmesine bağlı olması toplum ve kaos arasındaki uzlaşmaz çelişkiyi bir anlamda açıklamaktadır.

Bauman, özgürlük ya da bireyin özgürleşmesi ise toplumun kavrayabilme ve onun dinamikleri içerisinde bireyin sorumluluğunu ya da ödevini anlamlandırabilme yetisini içerisinde barındırmasını ve toplumun (yani, kapsamlı, sağlam temelli ve etkin

History of Consciousness and Idea of Order in Renaissance, England, Oxford, Oxford University Press, England, 1989.

${ }^{4}$ Zygmunt Bauman, Modernlik ve Müphemlik, Çev. İsmail Türkmen, Ayrıntı Yayınları, İstanbul, 2003, s.17.

${ }^{5}$ Zygmunt Bauman, Parçalanmış Hayat: Postmodern Ahlak Denemeleri, Çev. İsmail Türkmen, Ayrıntı

Yayınları, 2001, s.25. 
şekilde korunan kısıtlamalar ve kurallar sisteminin) gerekliliğini özgürlüğün sınırlarını etrafında tartışan filozofların argümanlarının mümkün olup olmadığını sorgulamaktadır. Bu noktada iki argüman ekseninde toplumsal baskıyı ve normatif düzenlemeler tarafından bireysel özgürlük üzerine dayatılan kısıtlamaları, "herkesin herkese karşı savaşı" karşısında insanların birlikteliklerini korumak için gerekli, kaçınılmaz ve nihayetinde hayırlı ve faydalı araç olarak, "nefret dolu, vahşi ve kısa bir hayat" karşısında insanların koruyucuları olarak temsil etti. Söz konusu argüman ise; Toplumsal baskının sona ermesinin, tabii böyle bir sona erme herhangi bir şekilde mümkünse ya da tasavvur edilebilirse eğer, insanları özgürlüğe kavuşturamayacă̆ını; aksine, yalnızca insanlar kendi antisosyal temelli içgüdülerinin hastalıkl baskılarına direnemez hale getireceğini iddia etmekteydiler. Diğer argüman ise "toplumsal olarak uygulanan normatif düzenlemelerin gerekliliğini, aslında kaçınılmazlı̆̆ın, böylece de bireysel özgürlük üzerindeki toplumsal kısıtlamaları savunan" argümanın tam tersi noktasında temellendirilmiştir.

$\mathrm{Bu}$ önerme ise; Emmanuel Levinas ${ }^{6}$ ve Knud Logstrup tarafından etraflıca işlenen bu yoruma göre, toplum aslında, esas itibariyle koşulsuz ve sınırsız Öteki'nekarş1-sorumluluğu, ya da "etik talebin" sonsuzluğunu, insanın başa çıkma ve üstesinden gelme kabiliyetine daha yakın bir düzeyde bir dizi emir ve yasaklamaya indirgeme amaçlı bir mekanizmadır. Normatif düzenlemenin asıl işlevi ise ayrıca kaçınılmazlığının da en önemli kaynağı, sorumluluğun yerine getirilmesini (Levinas) ya da etik talebe itaat etmeyi (Logstrup), toplumun düşünülebilir olması için azizlik standartlarının altında kalan sıradan insanlar için gerçekçi bir vazife haline getirmektedir. Bu anlamda Levinas toplumun nasıl doğduğunu sormaktadır, özetle: Toplum, üyelerinin bencil, saldırgan eğilimlerini dayanışma göreviyle dizginlemesinin ürünü müdür, yoksa aksine, üyelerinde görülen sınırsız diğerkâmlığı "bencillik buyruğuyla yumuşatmasının sonucu mudur? ${ }^{7}$

Bauman ise Levinas ve Logstrup'un argümanına yaklaşmakta yani etik sorumluluğun insanüstü sınırsızlığını, sıradan bir insanın duyarlılığının, sıradan bir insanın muhakeme gücünün ve eyleyebilme yeteneğinin kapasitesine

\footnotetext{
${ }^{6}$ Levinas, benliğin başka insanlarla, ötekilerle olan ilişkisine dair fenomenolojik bir araştırmadan yola çıkarak, iyinin doğru karşısında mutlak bir önceliği olduğunu savunmuştur. Levinas bu çıkış noktasından hareketle, insanın Ötekiyle olan ahlaki ilişkisinden (kişisel çıkar) önce geldiğini savunmuştur. Onun gözünde Öteki kişi mutlak olarak Öteki'dir, yani o şeylerin varlığı hakkındaki düşüncenin ya da bilginin ötesindedir. Öteki kişiyle olan yüz yüze ilişkisi insanı, Levinas'a göre, kendisinden önce Öteki'ne karşı sorumlu hale getirir. Şu halde, Ötekiyle, kavrayış ve ifadenin ötesinde bir ilişkiye bağımlı olan ahlaki bir yükümlülük ve fedakarlık etiğinin savunuculuğunu yapan Levinas, bu Öteki'ne sonsuzluk adını vermiştir. Levinas'ın sözünü ettiği Öteki, Aynının düzenine yabancı olan mutlak indirgenemez bir Öteki'dir. Öteki başkalarıyla ilişki içinde ortaya çıkar ve bu, ilişki eşsiz bir sorumluluk ilişkisidir. Dolayısıyla, özne ya da benlik de, ona göre, kendisi için olmanın ilkliğinden evvel, önce ötekisi için vardır. Özne varlığa, sadece hep ötekinden sorumlu olarak gelir. Ona göre, ben kendimi bir özne olarak inşa ederken, sorumlu hale gelirim. Sorumlu olmak kendimin bir özne olarak kuruluşudur. Bkz. Ahmet Cevizci, Emmanuel Levinas Maddesi, Felsefe Sözlügü, Paradigma Yayınları, Ankara, 2005.

${ }^{7 Z y g m u n t ~ B a u m a n, ~ E t i g ̆ i n ~ T u ̈ k e t i c i l e r ~ D u ̈ n y a s ı n d a ~ B i r ~ S ̧ a n s ı ~ V a r ~ M \imath ?, ~ C ̧ e v . F . ~ C ̧ o b a n, ~ I ̇ . K a t ı r c ı, ~ D e k i ~ Y a y ı n l a r ı, ~}$ Ankara, 2010, s.44-45.
} 
indirgenmesinden yola çıkmaktadır. O'na göre etik, tek ahlak kuralı, her ahlaklı kişinin itaat etmek zorunda olduğu birbiriyle tutarlı ilkelerden oluşan tek buyruklar grubudur. Etik ona göre, insani tarz ve ideallerin çoğulluğunu bir tehdit olarak, ahlaki yargıların müphemliğini ise düzeltilmesi gerekli marazi bir durum olarak görmektedir. Modern dönemde ahlak felsefecilerinin yapmaya çalıştıkları şey de bu çoğulluğu azaltıp müphemlikten kurtulmaktır. ${ }^{8}$

Bauman'ın modern etiği müphemlikten kurtarma çabası daha önceleri etik vazife ile Öteki'ne gösterilen ahlaki ilgiyi kapsayan semantik alana bağlı olan sorumluluk ve sorumlu seçim kavramları, kendini gerçekleştirme ve risk hesaplama alanına kaydı ya da aktarıldı. Yani Öteki'ne karşı olan sorumluluk duygusu ya da "kardeşimin bekçisi olma"9 düsturu gittikçe önemini kaybetti ve onun yerine kendine karşı sorumluluğun ön plana çıkartıldığı, bunu kendine borçlusun ve sorumlu seçimler olarak ifade edilen tamamen bireyselliği vurgulayan yaklaşımlar ortaya çıktı. Bauman, Levinas'ın ortaya koyduğu etik yaklaşımının toplumu açılamada karşılaştığ güçlüklerin sebebini değişen toplumsal ilişkinin özünde aramaktadır. Söylem köklü bir değişime uğramış ya da uğratılmıştır. Artık "bir şeye karşı olan sorumluluğun" (refah, bağımsızlık ve eylemin yöneltildiği taraftaki bir başka insanın onuruna karşı sorumluluğun) yerine, "bir şeyin önünde sorumluluğun" (üst konumdaki bir insanın, bir otoritenin, bir eylemin sebebi ile bu eylemi başlatan sözcülerin önünde sorumluluğun) getirilmesi değişen toplumsal ilişkilerde tekrar belirlenen önceliklerin göstergesidir. Değişen toplumsal ilişkilerin tekrar konumlandırılmasında ve tüketim temelli özgürlük yorumunun yaptığı sıçramanın kurbanı ise öteki'dir. ${ }^{10}$ Modern düşünce ahlakı, yaşama bir eklenti olarak görmektedir. Ontolojinin önceliği, yani insan birlikteliği vardır; ahlak sonradan toplumu bir arada tutacak harç işlevi görmektedir. Ahlak esnetilebilir, şekil verilebilir, belirlenebilir ya da yapıştırılabilir; dolayısıyla toplum da. İşte Bauman'ın, modernizm eleştirisinin temellerinden birisi bu ahlak görüşünü reddetmesiyle başlar. Ahlak her şekilde ontolojiden önce gelir bu yüzden de her kural koyma ediminde ortadan kalkmaktadır. Ontolojinin değil ahlakın önce gelmesi, hem ahlakın hem de toplumun çımaza sürüklenmesini beraberinde getirmektedir. ${ }^{11}$

Modern Etik ahlakın önceliğini değil toplumun birlikteliği ve düzenini kriter olarak ele aldığından, bireylerin gerçekleştirdikleri eylemlerde, postmodern-etik anlayışında olduğu gibi öteki'ni eyleminin ölçütü olarak ele almaz ele aldığı nokta toplumun kendisi ve birliği anlayışıdır. Levinas temelli postmodern-etik bireyin üzerindeki tüm iktidarları ortadan kaldırma amacındadır. Ötekini merkeze alan etik

\footnotetext{
8Zygmunt Bauman, Postmodern Etik, Çev., Ayrıntı Yayınları, İstanbul, 1998, s.33-34. Ayrıca bkz. Numan Kodal, Zygmunt Bauman'da Politika ve Etik, Yayınlanmamış Yüksek Lisans Tezi, Ankara Üniversitesi Sosyal Bilimler Enstitüsü Sosyoloji Anabilim Dalı, Ankara, 2005.

9 'Kardeşimin bekçisi olma' düsturuna ilişkin önemli bir tartışma için bkz. Ayşegül, Sabuktay, Kabil Etiğinden Levinas Etiğine, Bauman Sosyolojisi, der. Zülküf Kara, Ayrıntı Yayınları, İstanbul, 2013.

${ }^{10}$ Bauman, 2010, a.g.e., s.49.

${ }^{11}$ İsa Demir, Bauman'ın Modernizm Eleştirisi ve Eleştirinin İki Boyutu, Sosyoloji Notları, Sayı:2, 2007,s.30-31.
} 
anlayışı, modern etiğin birey üzerinde var olan otoriterliğini ortadan kaldırarak, eylemin sorumluluğunu eylemi yapan kişiye atfetmektedir.

\section{MÜPHEMLİK VE MODERNLIKK: UZLAŞMAZ SAFLARIN MÜCADELESİ}

Bauman, moderniteye Max Weber'in dünyanın büyüsünün bozulması ve bu sürece bağlı olan sekülerleşme ve rasyonelleşme görüşleri ekseninde yaklaşmaktadır. Büyünün bozulmasını sağlayan büyülü formül ise 'Tarih' ve 'Akıl'dır. Tarih ve aklın egemen kılınması dünyanın büyüsünün bozulmasını beraberinde getirmiştir. Etkileşim içerisinde olan bu iki kavramı Bauman "...tarihin akl, ya da aklın eseri olarak tarih, ya da aklın, tarih vasıtasıyla kendini bulan aklın, öz-arılaştırma süreci olarak tarih. Akıl, tarih olarak, henüz gerçekleşmeyen daimilik olarak, her yerden başka bir yer olarak ve her andan başka bir an olarak geliyordu. Akıl, bir fiil gibi davranan ve daima gelecek zamanda kullanılan ilginç bir isimdi; ve kafası tamamen amaçta olan şimdinin Akla itaat etmesi bekleniyordu çünkü bu kendi anlamın, başaracağı düşünülen amaçtan, hizmet ettiği bir projeden alıyordu. Yönetmek üzere olan Akıl, zamanı bağlayan ve geleceği denetleyen çabaya ortak olacak olan şimdiye anlam katıyordu..."12 şeklinde ifade etmektedir.

Tarih ve aklın yardımıyla şekillendirilen modern toplum kendi eğilimlerini, belirsizliğe dayanamama hali ile eş tutmaktadır. Modern toplumun kuruluşunun tarihselliğinin uç anlamda bir düzenleme/tahakküm ve kontrol altına alma eğilimi ekseninde ve bu düzen eğiliminin ise uç bir şekilde toplumu çıkmazlara götürdügünü vurgulayan Bauman müphemliğin, modernitenin belirsizliğe karşı olan tahammülsüzlüğün uzantısı olarak değerlendirmektedir. Modernite var olan düzensizliğe ve Kaos'a karşı, bireylerin düzen eğilimini yansıtmasının bir ifadesi olarak ortaya çıkmaktadır. Bauman müphemliği bir nesne ya da bir olayın birden fazla kategoriye sokulabilmesi olarak tanımlamakta ve onun dile özel bir düzensizlik olduğunu, yani dilin icra ettiği anlamlandırma (sınıflandırma) fonksiyonun iflası olarak değerlendirmektedir. Bu düzensizliğin temel belirtisi ise, belli bir durumu doğru biçimde okuyamamamız ve alternatif eylemler arasında seçim yapamadığımız zaman hissedilen kesin rahatsızlık olarak tanımlamaktadır. ${ }^{13}$

Tanımlanamayanın varlığı karşısında, öznenin kendisini ve çevresini tanımlayabilme sürecinde yaşadı̆̆ı çelişki, modernliğin felsefesine uygun düşmemekte ve yaşadığı toplum içerisinde ise eylem alanını sınırlandırmaktadır.

“...modernlik, bir düşünce meselesi, bir kaygı konusudur; kendi kendinin farkında olan, bilinçli bir pratik olduğunun bilincinde olan ve durduğu ya da sadece yavaşladığ 1 takdirde ortaya çıkacak pratikten sakınan bir pratik.." ${ }^{14}$ der Bauman modernlik için ve devam eder: "

"Modernliğin kendisine biçtiği ve aynı zamanda da modernliği oluşturan pek çok imkansız ödev arasında düzenleme ödevi (daha doğrusu ve daha önemlisi bir ödev olarak düzen) öne çıkmaktadır. Imkansız ödevlerin en imkansızı, vazgeçilmez ödevlerin en vazgeçilmezi

\footnotetext{
${ }^{12}$ Bauman, 2001, a.g.e., s.35.

${ }^{13}$ Bauman, 2003, a.g.e., s.13.

14 a.g.e., s.14.
} 
olarak, gerçekten de, bütün öteki ödevleri sadece kendisinin metaforu haline getiren bir ödev, bütün öteki ödevlerin arketipi olarak..."15

Müphemlik ise modernliğin tahammülsüzlüğün göstergesi olarak ortaya çıkan ve toplumun doğal halinin yansıması ve düzensizliğin aslında toplumsal düzenin kendisinin olduğunu anlatan, bir anlamda başkaldırı ve gerçeklik halidir. Müphemliğin, modernliğin katı hallerine karşı olan, esnek biçimleri söz konusu toplumsal yaşamda yeni direnç mekanizmaları ortaya çıkartmaktadır. Müphemliğin kökünü kazımak şeklinde ortaya çıkan kadim savaş, tipik bir modern pratiktir. Bu durum ise kesin olarak tanımlama ve kesin olarak tanımlanamayan her şeyin bastırılma ya da elenme çabası olarak ortaya çıkmaktadır. Belirsizliğe tahammülü olmayan şey ise doğa değil, modern pratiktir. Hoşgörüsüzlük burada modern pratiğin bir görüntüsüdür.

Müphemlik, modernliğin atık maddesidir. Hem düzen hem müphemlik, aynı şekilde modern pratiğin ürünleridir; bunların ikisinin de, modern pratiğin-süregiden ihtiyatlı pratiği- sürdürmekten başka çareleri yoktur. Müphemlik, herhalde modern dönemin en hakiki endişe ve kaygı kaynağıdır. Çünkü yenilen ve köleleştirilen öteki düşmanların aksine, müphemlik, modern güçlerin her başarısı ile birlikte daha da güçlenir. Düzenleme faaliyetinin müphemlik olarak yorumladığı şey aslında kendi başarısızlığıdır.

Düzenlilik ilkesini kendine düstur edinen modernliğin müphemlik ile mücadelesinde kesiştiği önemli bir kavram ise 'varoluş'tur. Varoluş, tasarım, manipülasyon, yönetim ve mühendisliğin etkisi altında olduğu ve bunlar tarafından sürdürüldüğü ölçüde moderndir. Varoluş, marifetli (yani, bilgi, beceri ve teknolojiye sahip) egemen failler tarafından yönetildiği ölçüde moderndir. Faillerse, varoluşu yönetme hakkına sahip çıktıkları ve bu hakkı başarıyla savundukları ölçüde egemendirler: Düzeni tanımlama ve bunun sonucu olarak da tanımlamadan kaçan artıklar olan kaosu bir tarafa itme hakkı olarak tanımlanan haktır. ${ }^{16}$

\section{MODERNLİK VE POSTMODERNLIKK DURUMLARININ İLIŞKİSELLİĞİ}

Bauman, modernliği, "Batı Avrupa"da, XVII. Yüzyıldaki bir dizi derin toplumsal, yapısal ve entelektüel dönüşümle başlayan ve Aydınlanma'nın gelişimiyle kültürel bir proje olarak; kapitalist ve daha sonra da komünist endüstri toplumunun gelişmesiyle de toplumsal olarak kurulan bir yaşam biçimi olarak olgunluğa erişen tarihsel bir dönem olarak tanımlamaktadır. Dolayısıyla modernlik, Bauman'ın kullandığı biçimiyle, modernizm değildir. Modernizm, -daha önceki dönemin birçok münferit entelektüel olayına kadar geriye doğru izlenebilse de- bu yüzyılın başında olgunlaşan ve geriye baktığımızda (Aydınlanma'yla analojik olarak) postmodern bir proje ya da postmodern durumun ilk belirtilerinin çıktığı evresi olarak görebileceğimiz entelektüel (felsefi, edebi, sanatsal) bir akım olarak tanımlamaktadır. ${ }^{17}$

\footnotetext{
${ }^{15}$ Bauman, 2003, a.g.e., s.13.

16 a.g.e., s.18.

${ }^{17}$ Bauman, 2003, a.g.e., s.13.
} 
Modernlik, Bauman'ın düşüncesinde düzenin aşırı tahakkümü sonucunda, toplumun kusursuz bir şekilde bir arada yaşamasının nasıl mümkün olabileceği sorusuna cevabının verilmesi istencini barındırmaktadır. Modernlik eleştirisini ise Holocaust kavramı etrafında gerçekleştirmektedir. Modern zaman çelişki ile var olmaktadır, bir yandan modernliğin sacayaklarından olan rasyonelliği bünyesinde barındırırken, diğer taraftan bitmek bilmeyen bir müphemlik üretimini beraberinde getirmektedir. Bu düzenleme ve tahakküm istenci Holocaust ${ }^{18^{\prime}}$ da vücut bulmuştur. Holocaust aklı araçsallaştıran görüşün iflasını ortaya koyması noktasında önem taşımaktadır. Bauman söz konusu insanlık suçunu modern üretim sistemi ile ilişkilendirirken şu cümleleri kullanmaktadır:

"(Auschwitz)... Modern fabrika sisteminin stradan bir uzantısıydı. Mal üretmekten ziyade ham maddesi insand ve nihai ürün, ölümdü; bu yüzden birçok birim her gün yöneticinin üretim çizelgesini dikkatli biçimde çiziyordu. Modern fabrika sisteminin tam da simgesi olan bacalar, yanan insan kokusunun ürettiği keskin kokuyu dışarıya boşaltıyordu. Modern Avrupa'nın parlak bir şekilde örgütlenmiş demiryolu şebekesi, fabrikalara yeni türden bir hammadde taşıyordu. Bunun diğer kargolar gibi aynı şekilde yapıyordu. Gaz odalarındaki kurbanlar, Almanya'nın gelişmiş kimya endüstrisi tarafindan üretilen prüsik asit hapları ile üretilen zehirli gazı teneffüs ediyorlardı. Mühendisler kremataryumu; idareciler, geri ulusların imrendiği bir heves ve verimlilik ile çalışan bürokrasi sistemini tasarlamışlardı. Planın tamamı bile, çarpık giden modern bilimsel ruhun bir yansımasıydı. Tanıklık ettiğimiz şey, kitlesel bir sosyal mühendislik şemasından başka bir şey değildi."19

Bauman, modernlik ile insanlık tarihinin en büyük suçlarından biri olan Holocaust'u ilişkilendirmekte ve bu olayın tesadüfi olmaktan çok öte modern toplumların bu tehlikeyi bünyelerinde barındırdığını ve bu noktadan hareketle Holocaust modern toplumda bir sapma değil tam da modernliğin oluşturduğu iklimin doğal bir sonucu olarak meydana gelmiştir. Holocaust gibi bir olgunun nedeni ise her şeyi düzenleyen ve her şeye şekil vermeye çalışan araçsal akıl ile modern bürokrasidir. ${ }^{20}$

Bauman, postmodernlik düşüncesini modernliğin temel noktalarının eleştirisi üzerine kurmaktadır. Bu noktalardan en önemlisi ise, dünyanın ortadan kaldırılması imkansız çoğulluğunun yani farklı olanların varlığının kabulüdür. Bauman bu çoğulluğun henüz ulaşılamamış mükemmelliğe (gayri mükemmellikler çok ve farklıdır; mükemmellik ise, tanımı gereği, daima tektir) giden yoldaki geçici, er ya da geç arkada bırakılacak bir istasyon olmadığını, varoluşun kurucu niteliğinin bu çoğulluk olduğunu belirtmektedir. Postmodernlik müphemliğin üstesinden gelmeyi ve aynılığın tek anlamlı kesinliğini hedefleyen tipik modern güdüden tamamen özgürleşme anlamına gelmektedir Tek tip modern güdüden özgürleşme bireylere tahakküm niyetinin yokluğuna götürmektedir. Tahakküm niyetinin yokluğunda,

\footnotetext{
${ }^{18}$ Nazilerin Yahudileri kitleler halinde öldürmelerine verilen ad (y.n.).

${ }^{19}$ Zygmunt Bauman, Holocoust ve Modernite, Çev. Süha Sertabiboğlu, Versus Yayınları, İstanbul, 2007.

${ }^{20}$ Mustafa Kemal Şan, Zygmunt Bauman: Modernlik ve Postmodernlik Arasında Bir Sosyolog, İstanbul Üniversitesi Sosyoloji Dergisi, c.3, s.11, İstanbul, 2006, ss.63-91.
} 
bireyler birbirlerini dışlayan standartların varlığına bağlı kalmamaktadırlar. Modernliğin getirdiği evrenselleştirme ilkesi, birlikte yaşama ilkesinin yerini almaktadır. Özgürlük, farklılık ve kardeşlik, modernliğin sloganı iken, özgürlük, farklılık ve hoşgörü ise postmodernliğin kavramları olarak ortaya çıkmaktadır. ${ }^{21}$ Bauman'ın postmodernist söylemi, modernite fikrinde içerilen, Batı toplumunun kendi kendisine atfettiği niteliklerin bugün geçerli olmadığını, belki dün de geçerli olmamış olduğunu ima etmektedir. Yeni farkındalık olarak adlandırılan postmodernite modernite hakkındaki bilgimizi tekrar düzenlemekte ve onun değişik yönlerine atfettiğimiz önemi yeniden belirlemektedir. Değişik yönlere atfedilen önem ise, toplumsal düzen açısından birbirinden farklı sayıdaki yaşam biçiminin var olduğu bir yaşama uyum sağlamaktır. ${ }^{22}$

Modernliğin kendi yarattı̆̆1 toplumsal düzeni! koruyabilmek için başvurduğu aklın araçsallaştırılması ve tek tipleştirmenin her şeyin önüne geçebileceği düşüncesi, toplumsal travmaları da beraberinde getirmiş ve hoşgörüsüzlügüün ve Öteki'nin yaşam hakkının gerektiği zamanlarda lütfedilmesine! neden olmuştur. Bauman'ın, postmodernliğin dayandığı kavramların (özgürlük, farklılık ve hoşgörü) somutlanabildiği bir toplum düşüncesi ise toplumsal düzeni mükemmelliğe ulaştırma çabasını başat hedef olarak almasa da birlikte yaşanabileceği ve farklı olana saygının var olduğu bir toplum imgesi kurmaktadır. Bu toplum ise farklılıkların, tek tipleştirmelere karşı önceliğinin olduğu bir toplumdur.

\section{SONUÇ}

Günümüz sosyolojisinin önemli temsilcileri arasında yer alan Bauman, modernliğin çıkmazlarından hareket ederek postmodernlik, etik ve müphemlik üzerinden toplum ve değişimi tartışmalarını gerçekleştirmiştir. Modern toplumun çıkmazlarının, toplumun tıpkı doğa halinde yansıtılan Hobbesçu anlamdan farklı olduğunu ve önemli olanın saf toplumsal düzen için otoriter yaklaşımların etkin kılınması değil, toplumda bir arada yaşamaya çalışan ve birbirinden farklı olan kesimlerin farklılıklarının, diğer kesimler için rahatsız edici olmamasıdır. Bu yaklaşım ekseninde yeniden tanımlamaya çalıştığı postmodernlik ve bağlantılı olduğu etik anlayışın temelleri öteki için olmak düsturunun temellerini oluşturmaktadır. İnsanlık tarihinin en büyük trajedilerinden olan Holocaust'1 yaratan faktörlerin modernliğin temel dinamiklerinden kaynaklanmasının bir tesadüf olmadığını vurgulaması ise toplumsal düzeni aşırı kontrol edilebilirlik anlayışı ile ilişkilendirmenin sonuçlarını göstermesi bakımından önem taşımaktadır. Toplumu bir örtünme operasyonu olarak değerlendirmesi ve bu örtünün müphemlik tarafından delik deşik edilmesinin, modernliğin düzen kaygısının başarısızlığını vurgulaması yaşanılan dönemin toplumsal pratiklerinin neler olduğunun anlaşılmasını kolaylaştırmaktadır.

\footnotetext{
${ }^{21}$ Bauman, 2003, a.g.e., s.131.

22Zygmunt Bauman, Yasa Koyucular ve Yorumlayıcılar, Çev. Kemal Atakay, Metis Yayınları, İstanbul, 1996, s.143-145.
} 


\section{KAYNAKÇA}

Bauman, Z. (1996). Yasa Koyucular ve Yorumlayıcılar. Çev. Kemal Atakay, İstanbul: Metis Yayınlar1. (1998). Postmodern Etik. Çev. Alev Türker, İstanbul: Ayrıntı Yayınları. (2001a). Bireyselleşmiş Toplum, Çev. Yavuz Alagon, İstanbul: Ayrıntı Yayınları. (2001b). Parçalanmış Hayat: Postmodern Ahlak Denemeleri, Çev.İsmail Türkmen, İstanbul: Ayrintı Yayınları. (2003). Modernlik ve Müphemlik, Çev. İsmail Türkmen, İstanbul: Ayrıntı Yayınları. (2007). Holocoust ve Modernite, Çev. Süha Sertabiboğlu, İstanbul: Versus Yayınları. (2010). Etiğin Tüketiciler Dünyasında Bir Şansı Var Mı?, Çev.F. Çoban, İ.Katırcı, Ankara: Deki Yayınları.

Cevizci, A. (2005). Emmanuel Levinas Maddesi, Felsefe Sözlüğü, Ankara: Paradigma Yayınları.

Collins, L. S. (1989). From Divine Cosmos to Sovereign State: An Intellectual History of Consciousness and Idea of Order in Renaissance, England, England: Oxford University Press.

Demir, İ. (2007). Bauman'ın Modernizm Eleştirisi ve Eleştirinin İki Boyutu, Sosyoloji Notları, 3031.

Kodal, N. (2005). Zygmunt Bauman'da Politika ve Etik, Yayınlanmamış Yüksek Lisans Tezi, Ankara Üniversitesi Sosyal Bilimler Enstitüsü, Sosyoloji Anabilim Dalı, Ankara.

Sabuktay, A. (2013). Kabil Etiğinden Levinas Etiğine, Bauman Sosyolojisi, Der. Zülküf Kara, İstanbul: Ayrıntı Yayınları.

Şan, M.K. (2006). Zygmunt Bauman: Modernlik ve Postmodernlik Arasında Bir Sosyolog, İstanbul Üniversitesi Sosyoloji Dergisi, 63-91. 